\title{
Comparison of fattening performances of Large White, Belgian Landrace and Cross-Bred pigs
}

\author{
J. LOUGNON \\ A. E. C., Société de Chimie organique et biologique, \\ 03600 Commentry
}

A single feed ( 3300 digestible kcal, I 7.5 p. Ioo of crude protein) was given ad libitum to pigs weighing between 20 and $95 \mathrm{~kg}$. The animals were either Large White $(L W)$ or Belgian Landrace $(L B)$ or Cross-Bred (CR) (half castrated males, half females).

The daily mean intake of the females was Io p. Ioo lower than that of the males. The $L B$ pigs consumed $5 \mathrm{p}$. Ioo less feed than the $L W$, and the $C R 5 \mathrm{p}$. Ioo more. The $L B$ reached $90 \mathrm{~kg}$ 7 days later and the $C R$ I 6 days earlier than the $L W$. Feed efficiency was the highest in the $C R$ pigs and the lowest in the $L B$ pigs.

As regards body composition, carcasses of the females were of better quality than those of the castrated males (loin/backfat ratio : $+38 \mathrm{p}$. roo). As compared with $L W$, this ratio was 27 p. Ioo higher in $C R$ and 50 p. Ioo higher in $L B$. When fed ad libitum and on a free choice, a cereal-based diet ( 9.5 p. 100 of crude protein) and a complementary feet (50 p. roo of crude protein), $L W$ and $L B$ pigs (castrated males and females) consumed a ration the protein level of which gradually decreased from about $20 \mathrm{p}$. roo at $30 \mathrm{~kg}$ live weight, to $\mathrm{I} 4 \mathrm{p}$. Ioo in $L B$ of both sexes and in $L W$ females and to I2.5 p. Ioo in castrated $L W$ after $60 \mathrm{~kg}$ live weight.

\section{Factors affecting selection of boars in a closed line with a low degree of inbreeding}

\author{
J. NAVEAU \\ Institut Technique du Porc, \\ Service Selection. \\ 149 , we de Bercy, \\ 75579 Paris Cedex 12
}

The aim of this study was to establish a programme for the selection and utilization of boars in a closed line with a low degree of inbreeding.

If we admit that it is necessary to have at least 4 boars on service simultaneously, this study may lead to the following simple rule :

Every 2 I days, selection of a new young boar and elimination of the boar which has alreadyperformed the greatest number of services.

On condition of an equivalent utilization of each boar and of a random mating programme excluding sib or half-sib matings, this method may give the following results : 